\title{
Structure Contour and Overburden Maps of the Niobrara Interval of the Upper Cretaceous Cody Shale in the Bighorn Basin, Wyoming and Montana
}

By Thomas M. Finn

Pamphlet to accompany

Scientific Investigations Map 3457 


\title{
U.S. Department of the Interior \\ DAVID BERNHARDT, Secretary
}

\author{
U.S. Geological Survey \\ James F. Reilly II, Director
}

U.S. Geological Survey, Reston, Virginia: 2020

For more information on the USGS - the Federal source for science about the Earth, its natural and living resources, natural hazards, and the environment—visit https://www.usgs.gov or call 1-888-ASK-USGS.

For an overview of USGS information products, including maps, imagery, and publications, visit https://store.usgs.gov/.

Any use of trade, firm, or product names is for descriptive purposes only and does not imply endorsement by the U.S. Government.

Although this information product, for the most part, is in the public domain, it also may contain copyrighted materials as noted in the text. Permission to reproduce copyrighted items must be secured from the copyright owner.

Suggested citation:

Finn, T.M., 2020, Structure contour and overburden maps of the Niobrara interval of the Upper Cretaceous Cody Shale in the Bighorn Basin, Wyoming and Montana: U.S. Geological Survey Scientific Investigations Map 3457, scale 1:500,000, 2 sheets, 9 p. pamphlet, https://doi.org/10.3133/sim3457.

Associated data for this publication:

Finn, T.M., 2020, Tops file for the Niobrara interval of the Upper Cretaceous Cody Shale and associated strata in the Bighorn Basin, Wyoming and Montana: U.S. Geological Survey data release, https://doi.org/10.5066/P9YEQ06X.

ISSN 2329-132X (online) 


\section{Contents}

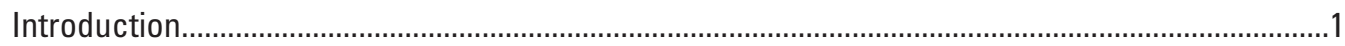

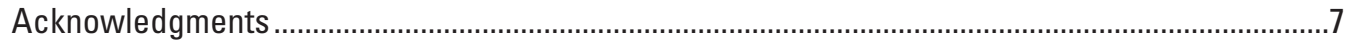

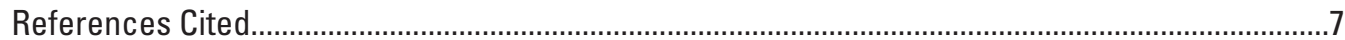

\section{Sheets}

1. Structure Contour Map of the Base of the Niobrara Interval of the Upper Cretaceous Cody Shale in the Bighorn Basin, Wyoming and Montana, available for downloading from https://doi.org/10.3133/sim3457.

2. Depth to the Base of the Niobrara Interval of the Upper Cretaceous Cody Shale in the Bighorn Basin, Wyoming and Montana, available for downloading from https://doi.org/10.3133/sim3457.

\section{Figures}

1. Map of the Rocky Mountain region showing locations of Laramide basins ......................2

2. Index map of the Bighorn Basin in north-central Wyoming and south-central Montana showing major structural elements and principal oil and gas fields..................3

3. Generalized geologic map and cross section of the Bighorn Basin in north-central Wyoming and south-central Montana

4. Correlation diagram of the Upper Cretaceous Cody Shale and associated strata in the Bighorn Basin, Wyoming and Montana ....................................................................

5. Type log of the Niobrara interval and associated strata in the Pike Resources Federal 1-15 well in the southeastern part of the Bighorn Basin

\section{Conversion Factors}

U.S. customary units to International System of Units

\begin{tabular}{|c|c|c|}
\hline Multiply & By & To obtain \\
\hline \multicolumn{3}{|c|}{ Length } \\
\hline foot $(\mathrm{ft})$ & 0.3048 & meter $(\mathrm{m})$ \\
\hline mile (mi) & 1.609 & kilometer (km) \\
\hline \multicolumn{3}{|c|}{ Area } \\
\hline square mile $\left(\mathrm{mi}^{2}\right)$ & 2.590 & square kilometer $\left(\mathrm{km}^{2}\right)$ \\
\hline
\end{tabular}

\section{Datum}

Horizontal coordinate information is referenced to the North American Datum of 1983 (NAD 83).

Altitude, as used in this report, refers to distance above sea level. 



\title{
Structure Contour and Overburden Maps of the Niobrara Interval of the Upper Cretaceous Cody Shale in the Bighorn Basin, Wyoming and Montana
}

\author{
By Thomas M. Finn
}

\section{Introduction}

The Bighorn Basin is a complex intermontane sedimentary and structural basin that formed during the Laramide orogeny (Late Cretaceous through early Eocene). The basin is nearly 180 miles (mi) long, $100 \mathrm{mi}$ wide, and covers approximately 10,400 square miles $\left(\mathrm{mi}^{2}\right)$ in north-central Wyoming and a small part of south-central Montana (fig. 1). The basin is bounded on the northeast by the Pryor uplift, on the east by the Bighorn uplift, and on the south by the Owl Creek uplift (fig. 2). The northern boundary of the Bighorn Basin is formed by the Nye-Bowler lineament, a regional anticlinal trend extending about $60 \mathrm{mi}$ east-southeast from the northern part of the Beartooth uplift to the Pryor uplift (figs. 1 and 2). This trend consists of a series of highly faulted anticlines and domes that Wilson (1936) interpreted to overlie a left-lateral basement shear zone. The Nye-Bowler lineament forms the structural divide separating the Bighorn Basin to the south from the Reed Point syncline and Crazy Mountains Basin to the northwest (fig. 1). The northwest and west margins are formed by the Beartooth uplift and Absaroka volcanic field, respectively (fig. 2). The basin margins are characterized by highly folded and faulted sedimentary rocks that range from Paleozoic to Paleocene in age; whereas, the central part of the basin is covered by nearly flat-lying lower Eocene and undifferentiated Tertiary and Quaternary rocks that mask the structure in the central part of the basin (fig. 3).

According to Hewett and Lupton (1917) and Berry (1952), oil was first discovered in the Bighorn Basin in 1884 emanating from the Upper Cretaceous Mowry Shale at a seep near what is now the Bonanza field along the east margin of the basin (fig. 2). This discovery led to the drilling of several shallow wells in the area; however, no oil or gas was found in commercial amounts (Berry, 1952; Biggs and Espach, 1960). It wasn't until 1906 that the first commercial hydrocarbon production in the Bighorn Basin was established from Cretaceous reservoirs at Garland field followed by the discovery of Greybull field in 1907 (Biggs and Espach, 1960; Fox and Dolton, 1996) (fig. 2). Since then, many important conventional oil and gas resources have been discovered and produced from reservoirs ranging in age from Cambrian to
Tertiary (fig. 2) (De Bruin, 1993; Fox and Dolton, 1996). In addition, a potential continuous (unconventional) basincentered gas accumulation may be present in Cretaceous reservoirs in the deeper parts of the basin (Ryder, 1987; Spencer, 1987; Surdam and others, 1997; Johnson and Finn, 1998a; Johnson and others, 1999; Finn and others, 2010). Numerous authors (see for example, Burtner and Warner, 1984; Hagen and Surdam, 1984; Meissner and others, 1984; Ryder, 1987; and Fox and Dolton, 1989, 1996) have suggested that various Upper Cretaceous marine shales are the principal hydrocarbon source rocks for many of these accumulations. With recent advances in horizontal drilling and multi-stage hydraulic fracture stimulation, equivalent Upper Cretaceous marine source rock intervals, in particular the Niobrara Formation, have become important shale gas or shale oil objectives in other Rocky Mountain Laramide basins (Matthews, 2011; Sonnenberg, 2011 Williams and Lyle, 2011; Durham, 2012a,b, 2013; Taylor and Sonnenberg, 2014; Hawkins, 2016). In the Bighorn Basin, the Niobrara is represented by shales, calcareous shales, marls, siltstones, and sandstones in the lower shaly member of the Cody Shale (Finn, 2014, 2019) (fig. 4).

The maps presented in this report were constructed as part of a project carried out by the U.S. Geological Survey (USGS) to better characterize the geologic framework of potential undiscovered continuous (unconventional) oil and gas resources of the Niobrara interval of the Upper Cretaceous Cody Shale in the Bighorn Basin in north-central Wyoming and south-central Montana (sheets 1 and 2). The structure contour map is drawn at the base of the "chalk kick" marker bed, a distinctive zone or peak on resistivity logs in the lower 50-300 feet (ft) of the Cody Shale that according to Finn $(2014,2019)$ represents the base of the Niobrara interval in the Bighorn Basin (fig. 5). This horizon was selected because it is easily identified on most well logs, is present throughout the basin, and was identified by the author in about 1,250 wells (Finn, 2020). In addition, about 20 wells in the deeper parts of the basin that penetrated the upper part of the Niobrara interval or overlying Cody Shale were utilized by projecting thicknesses from nearby wells and estimating a pick for the "chalk kick" marker (Finn, 2020). Along the shallow margins of the basin, many wells (about 60) were used that were drilled through the Niobrara interval; however, in these wells, the 


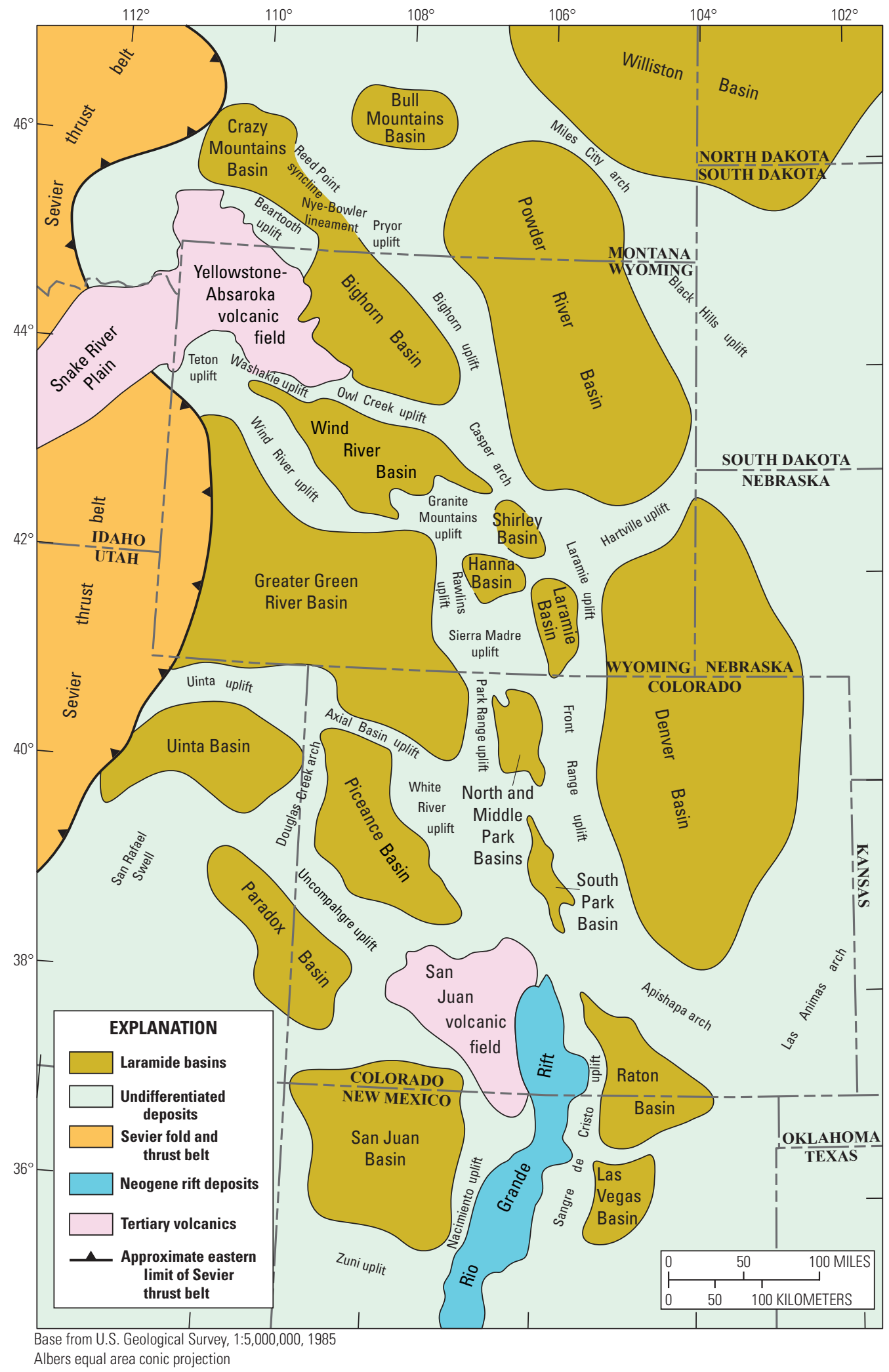

Figure 1. Rocky Mountain region showing locations of Laramide basins. 


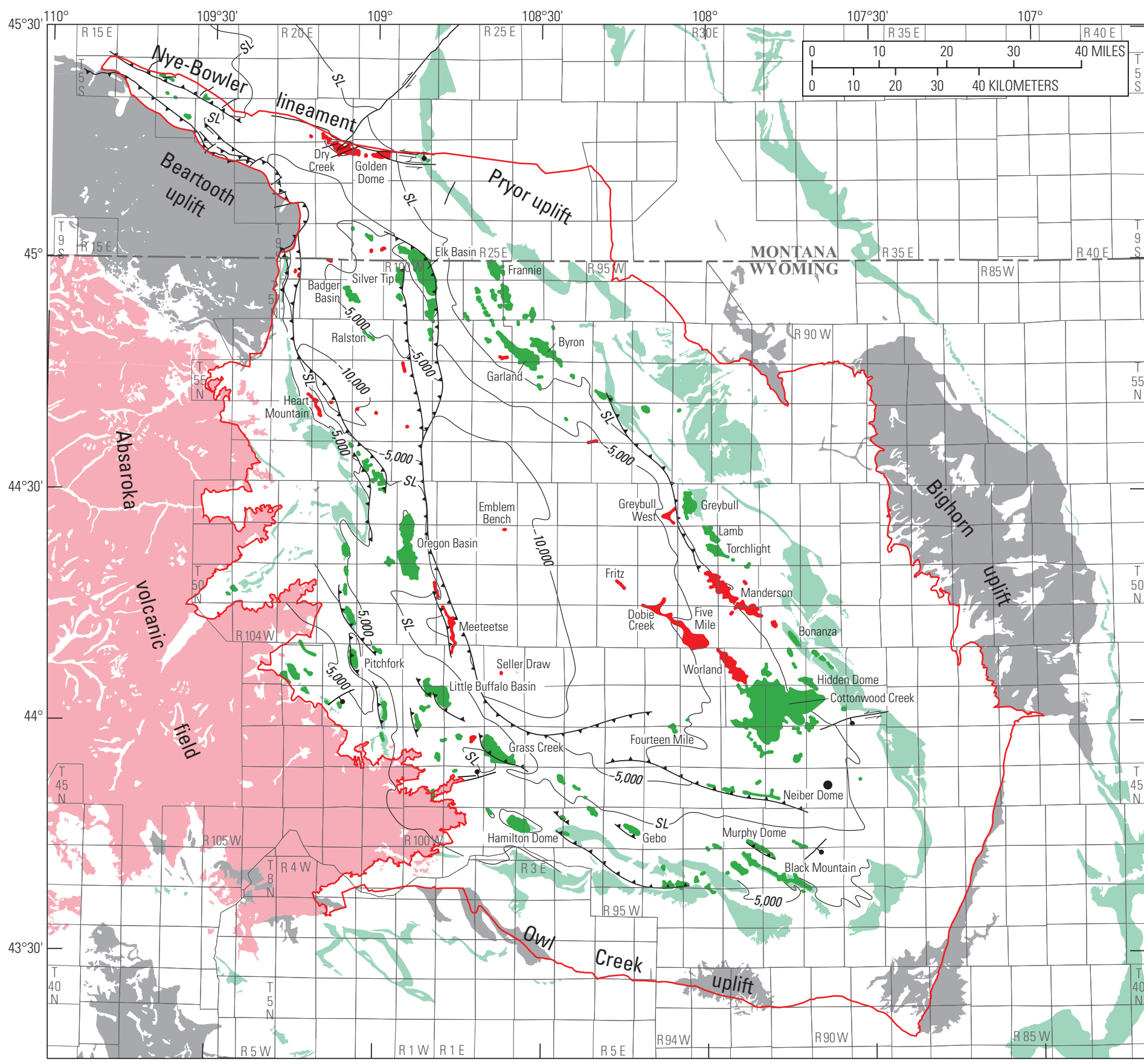

EXPLANATION

Tertiary volcanic rocks

Frontier Formation outcrop

Precambrian rocks

- Bighorn Basin boundary

Thrust fault-Sawteeth on upper plate

1. Normal fault-Bar and ball on downthrown block

_ High-angle fault

$\rightleftharpoons$ Strike-slip-Wrench fault; arrows

show relative movement

$-5,000$ - Structure contours-Base of

"chalk kick" marker bed.

Contour interval is 5,000 feet.

Byron 0il field

Fritz Gas field

- Pike Resources Federal 1-15 type log

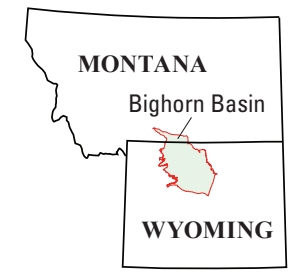

Base from U.S. Geological Survey digita data, 1:2,000,000, 2010

Lambert Conformal Conic projection

Central meridian $-107^{\circ} 30^{\prime} \mathrm{W}$.

Latitude of origin $41^{\circ} \mathrm{N}$., meters

North American Datum of 1983 (NAD 83)

Figure 2. Bighorn Basin in

north-central Wyoming and

south-central Montana showing

major structural elements and

principal oil and gas fields.

Structure contours are drawn

at the base of the "chalk kick"

marker bed of the Niobrara

interval of the Cody Shale.

Contour interval is 5,000 feet.

$\mathrm{SL}$, sea level. 

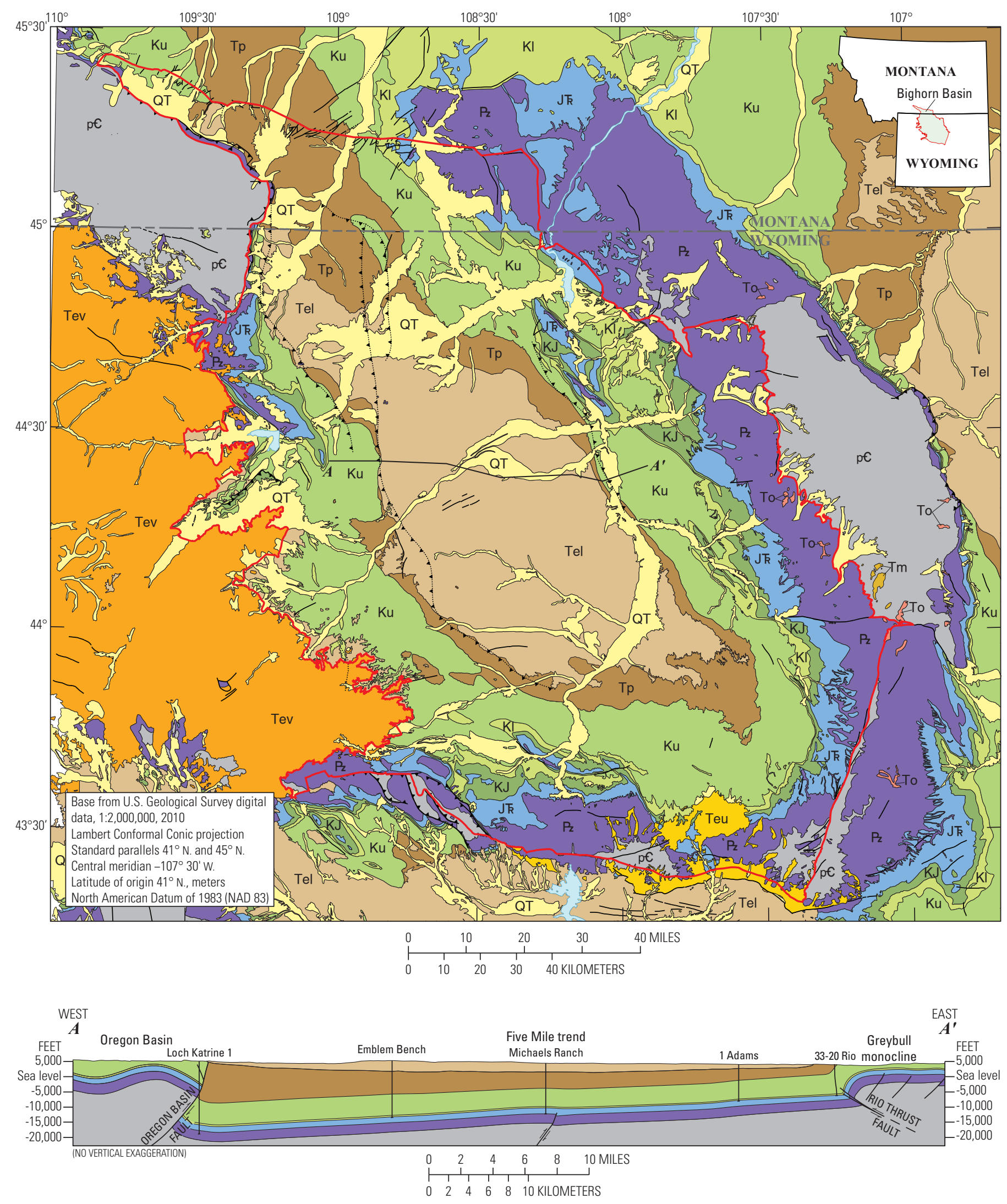

Figure 3 (above and following page). Bighorn Basin in north-central Wyoming and south-central Montana. Geologic map modified from Love and Christiansen (1985), Green and Drouillard (1994), and Raines and Johnson (1995). 


\section{EXPLANATION}

\begin{tabular}{|c|}
\hline QT \\
\hline Tm \\
\hline To \\
\hline Teu \\
\hline Tev \\
\hline Tel \\
\hline
\end{tabular}

\section{Water features}

Quaternary-Tertiary undifferentiated

Miocene(?) sedimentary rocks

Oligocene sedimentary rocks

Upper Eocene sedimentary rocks

Eocene volcanic rocks

Lower Eocene sedimentary rocks

\begin{tabular}{|c|c|}
\hline $\mathrm{Tp}$ & Paleocene sedimentary rocks \\
\hline $\mathrm{Ku}$ & Upper Cretaceous sedimentary rocks \\
\hline $\mathrm{KI}$ & Lower Cretaceous sedimentary rocks \\
\hline $\mathrm{KJ}$ & Lower Cretaceous-Jurassic sedimentary rocks \\
\hline JK & Jurassic-Triassic sedimentary rocks \\
\hline $\mathrm{P}_{2}$ & Paleozoic sedimentary rocks \\
\hline$p \epsilon$ & Precambrian crystalline rocks \\
\hline
\end{tabular}

Figure 3.-Continued Bighorn Basin in north-central Wyoming and south-central Montana. Geologic map modified from Love and Christiansen (1985), Green and Drouillard (1994), and Raines and Johnson (1995).

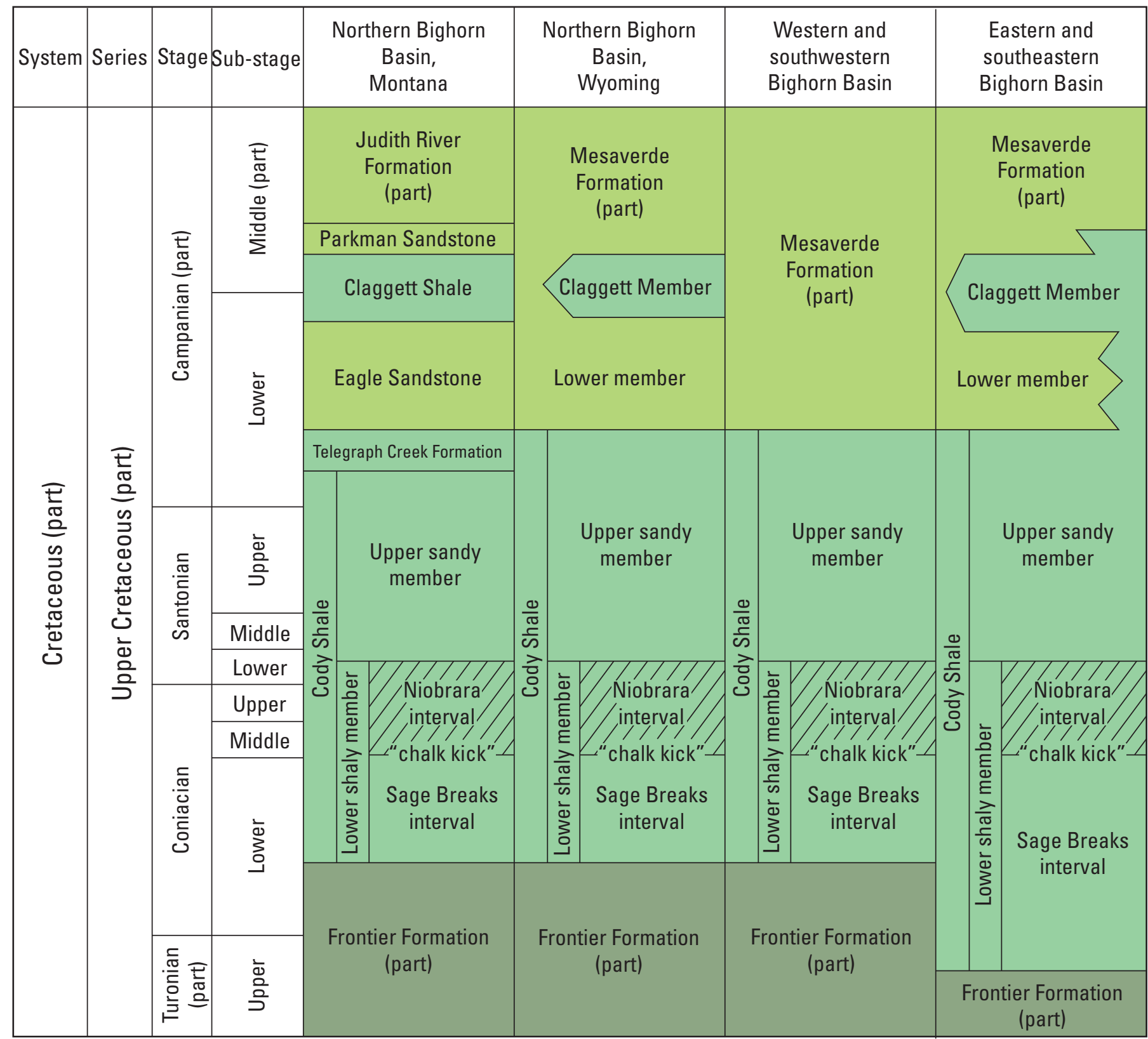

Figure 4. Upper Cretaceous Cody Shale and associated strata in the Bighorn Basin, Wyoming and Montana. 
API 4904320512

Pike Resources

Federal 1-15

section 15, T. 45 N., R. 90 W.

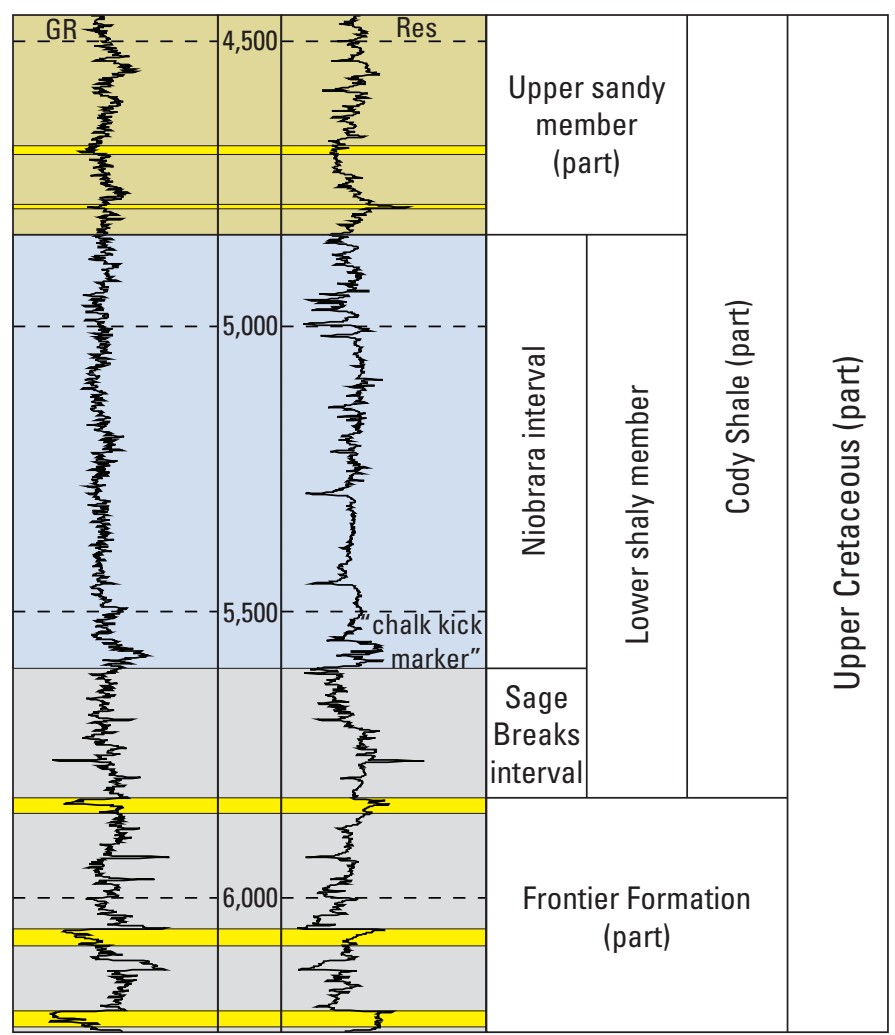

EXPLANATION

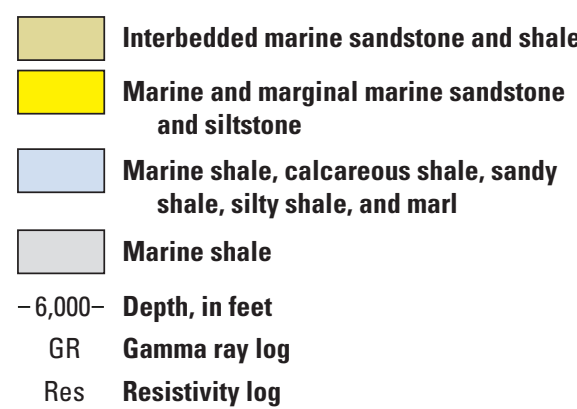

Figure 5. Niobrara interval and associated strata in the Pike Resources Federal 1-15 well in the southeastern part of the Bighorn Basin. Location shown in figure 2. GR, gamma ray log; Res., resistivity log. logging run was started in the underlying Frontier Formation. In these wells, the depth to the "chalk kick" marker was extrapolated up hole to estimate its depth to aid in contouring (Finn, 2020). The structure contouring is based on interpretation of the well data (Finn, 2020), surface geologic mapping by Love and Christiansen (1985), Green and Drouillard (1994), Raines and Johnson (1995), and Vuke and others (2007). Additional sources of geologic data include structural cross sections and (or) subsurface mapping by Stewart (1975), Stone (1975, 1983a,b, 1985a,b, 2004a,b), Tonnsen (1985), Ver Ploeg (1985), Bikis and Anderson (1986), Blackstone (1986a,b), Grauman and others (1986), Cardinal and others (1989), Johnson and Finn (1998b). The structure contour map is at a scale of 1:500,000, the contour interval is 1,000 $\mathrm{ft}$, and the datum is mean sea level (sheet 1). The overburden map was constructed by using the well data (Finn, 2020) and calculating the difference between the surface elevation and the structure contours. This map is at a scale of 1:500,000, and the contour interval is $1,000 \mathrm{ft}$ (sheet 2). 


\section{Acknowledgments}

This report benefited from reviews by Ron Drake, Michael Brownfield, Ofori Pearson, Janet Slate, and Dave Ferderer of the U.S. Geological Survey; their suggestions and comments are greatly appreciated.

\section{References Cited}

Berry, R.G., Jr., 1952, The geology of the Bonanza pool, Big Horn County, Wyoming, in Spalding, R.W., ed., Southern Bighorn Basin, Wyoming: Wyoming Geological Association, 7th Annual Field Conference Guidebook, p. 121-122. [Also available at http://archives.datapages.com/data/wga/data/007/ 007001/pdfs/121.pdf.]

Biggs, P., and Espach, R.H., 1960, Petroleum and natural gas fields in Wyoming: U.S. Bureau of Mines Bulletin 582, 538 p. [Also available from https://digital.library.unt.edu/ark:/ 67531/metadc38797/.]

Bikis, E.A., and Anderson, T.D., 1986, South Elk Basin Field—A case study, in Garrison, P.B., ed., Geology of the Beartooth uplift and adjacent basins: Yellowstone Bighorn Research Association Joint Field Conference and Symposium, Montana Geological Society 50th Anniversary Guidebook, p. 205-220. [Also available at http://archives.datapages.com/data/mgs/mt/ data/0040/0205/0205.html.]

Blackstone, D.L., Jr., 1986a, Structural geology—Northwest margin, Bighorn basin - Park County, Wyoming and Carbon County, Montana, in Garrison, P.B., ed., Geology of the Beartooth Uplift and adjacent basins: Yellowstone Bighorn Research Association Joint Field Conference and Symposium, Montana Geological Society 50th Anniversary Guidebook, p. 125-135. [Also available at http://archives.datapages.com/data/mgs/mt/data/0040/0125/ 0125.html.]

Blackstone, D.L., Jr., 1986b, Foreland compressional tectonics - Southern Bighorn Basin and adjacent areas, Wyoming: Geological Survey of Wyoming Report of Investigations no. 34, $32 \mathrm{p}$. [Also available at http://sales.wsgs.wyo.gov/foreland-compressional-tectonicssouthern-bighorn-basin-and-adjacent-areas-wyoming-1986/.]

Burtner, R.L., and Warner, M.A., 1984, Hydrocarbon generation in Lower Cretaceous Mowry and Skull Creek Shales of the northern Rocky Mountain area, in Woodward, J., Meissner, F.F., and Clayton, J.L., eds., Hydrocarbon source rocks of the greater Rocky Mountain Region. Rocky Mountain Association of Geologists Guidebook, p. 449-467. [Also available at http://archives.datapages.com/data/rmag/ SourceRocks84/burtner.htm.]
Cardinal, D.F., Miller, T., Stewart, W.W., and Trotter, J.F., eds., 1989, Wyoming oil and gas fields symposium; Bighorn and Wind River Basins. Wyoming Geological Association, $555 \mathrm{p}$. [Also available at http://archives.datapages.com/data/ wga/data/047/047001/1_wga0470001.htm.]

De Bruin, R.H., 1993, Overview of oil and gas geology of Wyoming, in Snoke, A.W., Steidtmann, J.R., and Roberts, S.M., eds., Geology of Wyoming - Geological Survey of Wyoming Memoir no. 5 p. 836-873. [Also available at http://sales.wsgs.wyo.gov/geology-of-wyoming-1993/.]

Durham, L.S., 2012a, Mancos-Niobrara play full of surprises: AAPG Explorer, v. 33, no. 8, p. 14-18. [Also available at https://explorer.aapg.org/story/articleid/1984/mancosniobrara-play-full-of-surprises.]

Durham, L.S., 2012b, What is the tally of Niobrara value?: AAPG Explorer, v. 33, no. 8, p. 20. [Also available at https://explorer.aapg.org/story/articleid/1987/what-is-thetally-of-niobrara-value.]

Durham, L.S., 2013, Rocky operators cautiously move ahead: AAPG Explorer, v. 34, no. 6, p. 6-8. [Also available at https://explorer.aapg.org/story/articleid/2490/rockyoperators-cautiously-move-ahead.]

Finn, T.M., 2014, Lower Cody Shale (Niobrara equivalent) in the Bighorn Basin, Wyoming and Montana-Thickness, distribution, and source rock potential: U.S. Geological Survey Scientific Investigations Report 2013-5138, 32 p., accessed March 17, 2019, at https://doi.org/10.3133/ sir20135138/.

Finn, T.M., 2019, Stratigraphic cross sections of the Niobrara interval of the Upper Cretaceous Cody Shale in the Bighorn Basin, Wyoming and Montana: U.S. Geological Survey Scientific Investigations Map 3422, pamphlet 19 p., 1 sheet [cross section], accessed February 2, 2019, at https://doi.org/10.3133/sim3422/.

Finn, T.M., 2020, Tops file for the Niobrara interval of the Upper Cretaceous Cody Shale and associated strata in the Bighorn Basin, Wyoming and Montana: U.S. Geological Survey data release, https://doi.org/10.5066/P9YEQO6X.

Finn, T.M., Kirschbaum, M.A., Roberts, S.B., Condon, S.M., Roberts, L.N.R., and Johnson, R.C., 2010, CretaceousTertiary Composite Total Petroleum System (503402), Bighorn Basin, Wyoming and Montana, chap. 3 of Petroleum systems and geologic assessment of oil and gas resources in the Bighorn Basin Province, Wyoming and Montana: U.S. Geological Survey Digital Data Series, Bighorn Basin Province Assessment Team, DDS-69-V, 146 p. [Also available as a CD-ROM, and at https://doi.org/10.3133/ds69v.]

Fox, J.E., and Dolton, G.L., 1989, Petroleum geology of the Wind River and Bighorn Basins, Wyoming and Montana, U.S. Geological Survey Open-File Report, p. 87-450P., 41 p. [Also available at https://doi.org/10.3133/ofr87450P.] 
Fox, J.E., and Dolton, G.L., 1996, Petroleum geology of the Bighorn Basin, north-central Wyoming and south-central Montana, in Bowen, C.E., Kirkwood, S.C., and Miller, T.S., eds., Resources of the Bighorn Basin: Wyoming Geological Association 47th Annual Field Conference Guidebook, p. 19-39. [Also available at http://archives.datapages.com/ data/wga/data/060/060001/19_wga0600019.htm.]

Grauman, J.E., French, D.E., and Tonnsen, J.J., 1986, Occurrences of petroleum and overview of drilling activity around the periphery of the Beartooth uplift, Montana and Wyoming, in Garrison, P.B., ed., Geology of the Beartooth uplift and adjacent basins: Yellowstone Bighorn Research Association Joint Field Conference and Symposium, Montana Geological Society 50th Anniversary Guidebook, p. 185-203. [Also available at http://archives.datapages.com/ data $/ \mathrm{mgs} / \mathrm{mt} / \mathrm{data} / 0040 / 0185 / 0185 . \mathrm{html}$.]

Green, G.N., and Drouillard, P.H., 1994, The digital geologic map of Wyoming in ARC/INFO format: U.S. Geological Survey Open-File Report 94-0425, 10 p. [Also available at https://doi.org/10.3133/ofr94425.]

Hagen, E.S., and Surdam, R.C., 1984, Maturation history and thermal evolution of Cretaceous source rocks of the Bighorn Basin, Wyoming and Montana, in Woodward, J., Meissner, F.F., and Clayton, J.L., eds., Hydrocarbon source rocks of the greater Rocky Mountain Region: Rocky Mountain Association of Geologists Guidebook, p. 321-338. [Also available at http://archives.datapages.com/data/rmag/ SourceRocks84/hagen.htm.]

Hawkins, S.J., 2016, Assessment of continuous (unconventional) oil and gas resources in the Late Cretaceous Mancos Shale of the Piceance Basin Province, Colorado and Utah, 2016: U.S. Geological Survey Fact Sheet 2016-3030, 4 p., accessed April 1, 2019, at https://doi.org/10.3133/ fs20163030.

Hewett, D.F., and Lupton, C.T., 1917, Anticlines in the southern part of the Big Horn Basin, Wyoming, a preliminary report on the occurance of oil: U.S. Geological Survey Bulletin 656, 192 p. [Also available at https://doi.org/10.3133/b656.]

Johnson, R.C., Crovelli, R.A., Lowell, B.A., and Finn, T.M., 1999, An assessment of in-place gas resources in the low-permeability basin-centered gas accumulation of the Bighorn Basin, Wyoming and Montana: U.S. Geological Survey Open-File Report 99-315-A, 123 p. [Also available at https://doi.org/10.3133/ofr99315A.]

Johnson, R.C., and Finn, T.M., 1998a, Is there a basincentered gas accumulation in Upper Cretaceous rocks in the Bighorn Basin? in Keefer, W.R., and Goolsby, J.E., eds., Cretaceous and Lower Tertiary rocks of the Bighorn Basin, Wyoming and Montana: Wyoming Geological Association 49th Annual Field Conference Guidebook, p. 257-273. [Also available at http://archives.datapages.com/data/wga/ data/062/062001/257_wga0620257.htm.]
Johnson, R.C., and Finn, T.M., 1998b, Structure contour map on the top of the Upper Cretaceous Mesaverde Formation, Bighorn Basin, Wyoming and Montana, in Keefer, W.R., and Goolsby, J.E., eds., Cretaceous and Lower Tertiary rocks of the Bighorn Basin, Wyoming and Montana: Wyoming Geological Association 49th Annual Field Conference Guidebook, p. 197-198. [Also available at http://archives.datapages.com/data/wga/data/062/062001/ 197_wga0620197.htm.]

Love, D.J., and Christiansen, A.C., 1985, Geologic map of Wyoming: U.S. Geological Survey, scale 1:500,000. [Also available at https://ngmdb.usgs.gov/Prodesc/proddesc 16366.htm]

Matthews, V., 2011, Colorado's new oil boom-The Niobrara: Colorado Geological Survey Rock Talk, v. 13, no. 1, 11 p. [Also available at https://store.coloradogeologicalsurvey.org/ product/rocktalk-oil-niobrara-colorado/.]

Meissner, F.F., Woodward, J., and Clayton, J.L., 1984, Stratigraphic relationships and distribution of source rocks in the greater Rocky Mountain region, in Woodward, J., Meissner, F.F., and Clayton, J.L., eds., Hydrocarbon source rocks of the greater Rocky Mountain region. Rocky Mountain Association of Geologists Guidebook, p. 1-34. [Also available at http://archives.datapages.com/data/rmag/ SourceRocks 84 /meissner.htm.]

Raines, G.L., and Johnson, B.R., 1995, Digital representation of the Montana state geologic map; a contribution to the Interior Columbia River basin ecosystem management project: U.S. Geological Survey Open-File Report 95-691, 20 p. [Also available at https://doi.org/10.3133/ofr95691.]

Ryder, R.T., 1987, Oil, gas, and coal resources of the McCullough Peaks Wilderness study area, Bighorn Basin, Wyoming: U.S. Geological Survey Open-File Report 87-646, 59 p. [Also available at https://doi.org/10.3133/ofr87646.]

Sonnenberg, S.A., 2011, The Niobrara Petroleum System-A new resource play in the Rocky Mountain Region, in Estes-Jackson, J.E., and Anderson, D.S., eds., Revisiting and revitalizing the Niobrara in the central Rockies. Rocky Mountain Association of Geologists, p. 13-32. [Also available at http://archives.datapages.com/data/rocky-mtngeologist-pubs/data/003/003001/13_rmag-bk0030013.htm.]

Spencer, C.W., 1987, Hydrocarbon generation as a mechanism for overpressuring in Rocky Mountain region: The American Association of Petroleum Geologists Bulletin, v. 71, no. 4, p. 368-388.

Stewart, W.W., 1975, Recent drilling in the Line Creek area of Wyoming and Montana, in Exum, F.A., and George, G.R., eds., Geology and mineral resources of the Bighorn Basin: Wyoming Geological Association 27th Annual Field Conference Guidebook, p. 203-208. [Also available at http://archives.datapages.com/data/wga/data/031/031001/ 203_wga0310203.htm.] 
Stone, D.S., 1975, Discovery of Silver Tip South field, Park County, Wyoming, in Exum, F.A., and George, G.R., eds., Geology and mineral resources of the Bighorn Basin: Wyoming Geological Association 27th Annual Field Conference Guidebook, p. 189-201. [Also available at http://archives.datapages.com/data/wga/data/031/031001/ 189_wga0310189.htm.]

Stone, D.S., 1983a, The Greybull Sandstone pool (Lower Cretaceous) on the Elk Basin thrust-fold complex, Wyoming and Montana, in Lowell, J.D., and Gries, R.R., eds., Rocky Mountain foreland basins and uplifts: Rocky Mountain Association of Geologists, p. 345-356.

Stone, D.S., 1983b, Seismic profile-South Elk Basin, in Bally, A.W., ed., Seismic expression of structural styles-A picture and work atlas: American Association of Petroleum Geologists Studies in Geology Series no. 15 , v. 3. p. 3.2.2-20-3.2.2-24. [Also available at http://archives.datapages.com/data/specpubs/oversiz1/data/ a185d/a185/0001/0000/0020.htm.]

Stone, D.S., 1985a, Geologic interpretation of seismic profiles, Bighorn Basin, Wyoming, Part I-East flank, in Gries, R.R., and Dyer, R.C., eds., Seismic exploration of the Rocky Mountain Region: Rocky Mountain Association of Geologists and Denver Geophysical Society, p. 165-174. [Also availble at $\mathrm{http}: / /$ archives.datapages.com/data/rmag/ seis_explor85/stone2.htm.]

Stone, D.S., 1985b, Geologic interpretation of seismic profiles, Bighorn Basin, Wyoming, Part II-West flank, in Gries, R.R., and Dyer, R.C., eds., Seismic exploration of the Rocky Mountain Region: Rocky Mountain Association of Geologists and Denver Geophysical Society, p. 175-186. [Also available at http://archives.datapages.com/data/rmag/ seis_explor85/stone3.htm.]

Stone, D.S., 2004a, Rio thrusting, multi-stage migration, and formation of vertically segregated Paleozoic oil pool at Torchlight field on the Greybull platform (eastern Bighorn Basin)-Implication for exploration: The Mountain Geologist, v. 41, no. 3, p. 119-138. [Also available at http://archives.datapages.com/data/rmag/mg/2004/stone.htm.]

Stone, D.S., 2004b, Structures of the Rocky Mountain foreland-Fivemile fault-related fold trend, central Bighorn Basin: The Mountain Geologist, v. 41, no. 3, p. 140-142. [Also available at http://archives.datapages.com/data/rmag/ $\mathrm{mg} / 2004 /$ stone $1 . \mathrm{htm}$.]

Surdam, R.C., Jiao, Z.S., and Heasler, H.P., 1997, Anomalously pressured gas compartments in Cretaceous rocks of the Laramide basins of Wyoming - A new class of hydrocarbon accumulation, in Surdam, R.C., ed., Seals, traps, and the petroleum system: American Association of Petroleum Geologists Memoir 67, p. 199-222. [Digital reprint available at https://www.aapg.org/publications/ special-publications/cds/details/articleid/4446/m67-cdtraps-seals-and-petroleum-systems.]
Taylor, J., and Sonnenberg, S.A., 2014, Reservoir characterization of the Niobrara Formation, southern Powder River Basin, Wyoming: The Mountain Geologist, v. 51, no. 1, p. 83-108, http://archives.datapages.com/data/mountaingeologist-rmag/data/051/051001/83_rmag-mg510083.htm, accessed February 5, 2019.

Tonnsen, J.J., ed., 1985, Montana oil and gas fields symposium 1985, volumes I and II: Montana Geological Society, 1,217 p. [Also available at https://mtgeo.org/shop/1985montana-oil-gas-fields/.]

Ver Ploeg, A.J., 1985, Tectonic map of the Bighorn Basin, Wyoming: Geological Survey of Wyoming [now the Wyoming State Geological Survey] Open-File Report 85-11, scale 1:250,000. [Also available at http://sales.wsgs.wyo.gov/ tectonic-map-of-the-bighorn-basin-wyoming-1985/]

Vuke, S.M., Porter, K.W., Lonn, J.D., and Lopez, D.A., 2007, Geologic map of Montana: Montana Bureau of Mines and Geology, Geologic Map 62, 2 sheets, scale 1:500,000. [Also available at http://www.mbmg.mtech.edu/mbmgcat/public/ ListPublications.asp]

Williams, P., and Lyle, D., 2011, Bring in the rigs, chap. 2 of Estes-Jackson, J.E., and Anderson, D.S., eds., Revisiting and revitalizing the Niobrara in the central Rockies: Rocky Mountain Association of Geologists, p. 33-40. [Also available at http://archives.datapages.com/data/rocky-mtngeologist-pubs/data/003/003001/33_rmag-bk0030033.htm.]

Wilson, C.W., Jr., 1936, Geology of the Nye-Bowler lineament, Stillwater and Carbon Counties, Montana: American Association of Petroleum Geologists Bulletin, v. 20, no. 9, p. 1161-1188. [Also available at http://archives.datapages.com/data/bulletns/1931-37/data/ pg/0020/0009/1150/1161.htm?doi=10.1306\%2F3D932E2016B1-11D7-8645000102C1865D.]

\section{Central Energy Resources Science Center}

Publishing support provided by the Science Publishing Network, Denver Publishing Service Center

For more information concerning the research in this report, contact the Center Director, USGS Central Energy Resources Science Center Box 25046, Mail Stop 939

Denver, CO 80225

(303) 236-1647

Or visit the Central Energy Resources Science Center website at https://www.usgs.gov/energy-and-minerals/energy-resources-program/ 


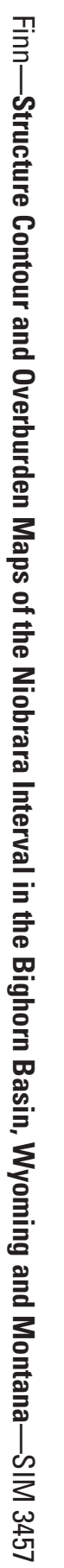

